\title{
HLA-A*0201-specific epitopes of Indian HIV-1C as candidates for vaccine design
}

\author{
Jagadish Chandrabose Sundaramurthi ${ }^{1^{*}}$, Luke Elizabeth Hanna² \\ From First International Science Symposium on HIV and Infectious Diseases (HIV SCIENCE 2012) \\ Chennai, India. 20-22 January 2012
}

\section{Background}

HLA alleles are associated with differential outcomes of infections/diseases. We hypothesize that epitopes that interact with HLA alleles associated with resistance elicit a protective immune response in the host, and could therefore serve as good vaccine candidates. Among the HLA alleles reported to be associated with resistance to HIV infection/slow progression to AIDS, HLA-A*0201 occurs most frequently in the Indian population. We undertook this study to identify HIV epitopes specific to this HLA allele from HIV-1C.

\section{Methods}

1769 sequences of all proteins of Indian HIV-1C were downloaded from the HIV sequence database and consensus sequence for each protein was built. Epitopes specific to HLA-A*0201, but not to any of the HLA alleles known to be associated with susceptibility to HIV/AIDS, were identified using ProPred1 and modeled on to HLA-A*0201.

\section{Results}

Twenty six peptides specific to HLA-A*0201 were identified as better binders to the HLA molecule than a control peptide which is a known immunodominant HIV epitope. Eleven of these have also been reported by others as immunogenic. Ten of the 11 epitopes were found to be conserved in Indie-C1, an infectious Indian subtype $\mathrm{C}$ clone. Four epitopes were reported to elicit $\mathrm{CD} 4+$ as well as CD8+ specific responses. Fifteen epitopes identified in this study are novel.

\footnotetext{
* Correspondence: jagadishnirt@gmail.com

'Division of Biomedical Informatics, Department of Clinical Research, National Institute for Research in Tuberculosis (formerly Tuberculosis Research Centre) (ICMR), Chennai, 600031, Tamil Nadu, India

Full list of author information is available at the end of the article
}

\section{Conclusion}

The short-listed epitopes could be tested for their potential as vaccine candidates for the Indian HIV epidemic. This approach has been extended to identify epitopes specific to other HLA alleles associated with resistance to HIV, and in vitro evaluation is being undertaken.

\section{Author details}

${ }^{1}$ Division of Biomedical Informatics, Department of Clinical Research, National Institute for Research in Tuberculosis (formerly Tuberculosis Research Centre) (ICMR), Chennai, 600031, Tamil Nadu, India. 'Division of HIV/AIDS,

Department of Clinical Research, National Institute for Research in Tuberculosis (formerly Tuberculosis Research Centre) (ICMR), Chennai, 600031, Tamil Nadu, India.

Published: 4 May 2012

\section{doi:10.1186/1471-2334-12-S1-015}

Cite this article as: Sundaramurthi and Hanna: HLA-A*0201-specific epitopes of Indian HIV-1C as candidates for vaccine design. BMC Infectious Diseases 2012 12(Suppl 1):015.

\section{Submit your next manuscript to BioMed Central and take full advantage of: \\ - Convenient online submission \\ - Thorough peer review \\ - No space constraints or color figure charges \\ - Immediate publication on acceptance \\ - Inclusion in PubMed, CAS, Scopus and Google Scholar \\ - Research which is freely available for redistribution

